\begin{tabular}{|r|l|l|l|l|l|}
\hline Revista Clío América & ISSN: 1909-941X & Vol. 11 & No. 22 & julio - diciembre de 2017 & 205 - 218 \\
\hline \multicolumn{6}{|c|}{ D0I: http://10.21676/23897848.2442 } \\
\hline
\end{tabular}

\title{
Two cycles of monetary easing in Mexico: 2009 And 2013-2014
}

Dos ciclos de relajamiento monetario en México: 2009 Y 2013-2014

Mario Rojas-Miranda

Phd in Economics, Research-Profesor of Economy at the Universidad del Istmo, Oaxaca, México. Email: mariorojas@bianni.unistmo.edu.mx; mariorojas15@hotmail.com ORCID: https://orcid. org/0000-0002-4883-2485

Oscar Rodríguez-Medina Master of Economics, Research-Profesor of Economy at the Universidad Nacional

Autónoma de México, México. Email: rodriguezmedinaoscar@gmail.com

ORCID: https://orcid. org/0000-0002-5839-2284

Tipologia: Artículo de revisión Fecha de recibido: agosto 16 de 2017 Fecha de aceptación: noviembre 21 de 2017

Publicado en línea: noviembre 27 de 2017

Para citar este artículo:

Rojas, M. M. \& Rodríguez, M. 0. (2017). Two cycles of monetary easing in México. Clio América, 11(22), 205-218. Doi: $10.21676 / 23897848.2442$
ABSTRACT: This paper provides an analysis of two cycles of monetary easing in Mexico. The first took place in 2009, during the global financial crisis, and the second occurred in 2013-2014, when the Mexican economy lost dynamism. In both periods, the actions taken by the Bank of Mexico provide ample evidence of its efforts to stabilize output and employment, while ceding importance to the fight against inflation and, in doing so, adopting a hierarchical mandate. The abundant global liquidity generated in developed countries by the great recession facilitated the monetary flexibilization in Mexico. A revision of official information from the Bank of Mexico in 2009 and 2013-2014 provides data on the cuts made to the reference rate, their periodicity, as well as their quantity. The two cycles of monetary expansion diminished the cost of money with the goal of incentivizing investment and consumption while counteracting the weakness of the Mexican economy.

Keywords: Bank of Mexico; monetary policy; Inflation Targeting; interest rate; inflation.

RESUMEN: El trabajo analiza dos ciclos de relajamiento monetario en México, el primero en 2009 con la crisis mundial y el segundo en 2013-2014 cuando la economía mexicana perdió dinamismo; para evidenciar las acciones de Banco de México por estabilizar en dos momentos el producto y el empleo, restándole importancia al combate a la inflación y en los hechos adoptando un mandato jerarquizado. La abundante liquidez mundial que se generó en los países desarrollados por la gran recesión facilitó la flexibilización monetaria en México. Mediante una revisión de información oficial de Banco de México en 2009 y 2013-2014, se presentan los recortes a la tasa de referencia, su periodicidad y su cuantía. Los dos ciclos de expansión monetaria disminuyeron el costo del dinero con el propósito de incentivar la inversión y el consumo y contrarrestar la debilidad de la economía mexicana.

Palabras clave: Banco de México; política monetaria; objetivos de inflación; tasa de interés; inflación.

JEL: E51, E52, E58 


\section{INTRODUCTION}

The Constitution of 1917 proposed the creation of a central bank under the charge of the Mexican state, which should act to reconstruct the monetary, creditary, and financial arms of the nation, re-establish public confidence in fiduciary funds lost due to the revolution, and provide the federal government with access to financing. Seven years later, the Banco de Mexico (BM) was finally created, emerging as the central bank of the Mexican state, an accomplishment achieved under the guise of the figure of a single emissory bank (Banco Único de Emision) (Ruiz, 2016). From the end of the Second World War to the beginning of the 1980s, the bank's primary objective was to channel resources into production and to provide financing, via primary credit, to the government in an effort to grow output and employment.

The pinnacle of these endeavors occurred in the 1970s under the so-called populist governments. However, in the 1990s came the arrival of the second liberal-leaning period of government in Mexico, during which time the central bank was transformed, its mandate being to centralize its efforts on safeguarding the acquisitive power of money, in other words, to combat inflation (Banco de Mexico, 1995; Carstens \& Reynoso, 1997). Subsequently, in the 21st century, BM has taken on a new strategic direction. Strengthened by its credibility and with a scaffold to separate it from the public, the institution has assumed a new role with a new goal: to stabilize output through counter-cyclical monetary policy.

This paper provides an analysis of two cycles of monetary easing in Mexico: the first in 2009 in the face of the global crisis, and the second in 2013-2014 when the Mexican economy lost momentum. This analysis shows how the Bank of Mexico made efforts to stabilize output and employment during both these periods, ceding importance to the fight against inflation and in so doing adopting a hierarchical mandate. A revision of the official information of $B M$ from 2009 and 2013-2014 provides data showing the cuts made to the reference rate, as well as both the periodicity and the quantity of said cuts. Furthermore, it will be shown how these two cycles of monetary expansion diminished the cost of money to incentivize investment and consumption and counteract the weakness of the Mexican economy.

This investigation is comprised of four parts: this first part provides an introduction with reference to the structural change undergone by BM and the effects on monetary policy via distinct channels of transmission. The second provides the methodology used, the third is about the results the analysis of the first cycle of monetary easing which occurred in 2009, and the second cycle of monetary easing which took place in 2013-2014. The paper then closes with conclusions and suggestions for further research.

In the 1980s Mexico undertook structural changes across all of its economic institutions, which entailed a gradual albeit irreversible transformation of every sector of the economy, with the goal of consolidating a flexible, unregulated market economy with no interference from the state in the fixing of public and (even less so of) private prices (Solis, 1997). Gradually the state ceased being a producer of goods and services, and public businesses began to be sold to private initiatives. The substitutive import model ceased to be dominant and a secondary export-based model was constructed in the commercial opening and through international competition (Aspe,1993). The most significant changes were evidenced in Mexico's entrance into the General Agreement on Tax and Trade (GATT) in 1986, which later would become the World Trade Organization (WTO), and the putting into motion of the North American Free Trade Agreement (NAFTA) between the United States, Canada, and Mexico in 1994 (Cabrera \& Rojas, 2006).

The structural change witnessed in Mexico encompassed both the fiscal and exchange sectors, as well as the monetary ambits. With respect to the latter, the reform was felt with even greater magnitude when, in 1993, article 28 of the Constitution was reformed, mandating to the Bank of Mexico the safeguarding of the acquisitive power of the peso and conceding to the BM full autonomy in the management of its internal net credit (Carstens \& Werner, 1999). In doing so, the reform impeded BM from granting financing to any authority. Moreover, 
this institutional redesign included the following elements: i) it eliminated the discretion by which the federal government could remove officials of the BM and ii) from 2011 onwards, the calculation of inflation became a task of the Instituto Nacional de Estadística y Geografía (INEGI). It must be noted that the institute was granted administrative and managerial autonomy, but not independence in its objectives, terms which remain enshrined in article 28 of the Constitution (CPEUM, 23-08-1993; Banco de Mexico, 1994; Banco de México, 1995; Turrent, 2010).

In the first years of the 21st century, Mexico experienced a drop in inflation which reached single-digit levels. In 2001, the BM adopted the Inflation Targeting Approach (ITA), a policy scheme widely recognized for its achievements in diverse developing countries (Bernanke, Laubach, Mishkin, \& Posen, 2001; Friedman, 1968; Friedman, 1991; Taylor, 1993; Taylor, 2000). The adoption of ITA was possible due to three pre-existing elements: i) the autonomy of the Central Bank, ii) the fight against inflation as its primary objective, iii) the increase of communication between the BM and the public. Short and medium-term inflation targets were made official: $10 \%$ in $2000,6.5 \%$ in $2001,4.5 \%$ in 2002 and $3 \%$ in 2003, with the latter to remain as a long-term goal with a variability interval of $+/$ - one percentage point. The national index of consumer prices was adopted with an emphasis on underlying inflation as the official indicator for compliance with inflation goals (Banco de Mexico, 2001).

As the years passed, prices maintained a lower, less volatile trajectory. From 1995 to 2000, observed inflation was greater than the target set by the authority. Nevertheless, the gap between observed inflation and the target set by the institute was contracting (Banco de Mexico, 2003a). From 2001 onwards, when the announcements on short and midterm goals were made by officials via ITA, the level of observed prices tended to settle around their target. This situation was consolidated after 2003 when inflation rounded to $3 \%$ and came to rest within the $+/-1$ percentage point interval-with the exception of 2009 when the international crisis impacted the Mexican economy (Sánchez, 2011). This panorama of lowered and less varied price formation provided a context during which the autonomy of the central bank, the flexible exchange type regime and the inflation target characterized Mexican monetary policy, as you see in Figure 1 (Banco de Mexico, 2009c; Banco de Mexico, 2010).

\section{Figure 1.}

\section{Inflation objectives and observed inflation from 1995 to 2016.}

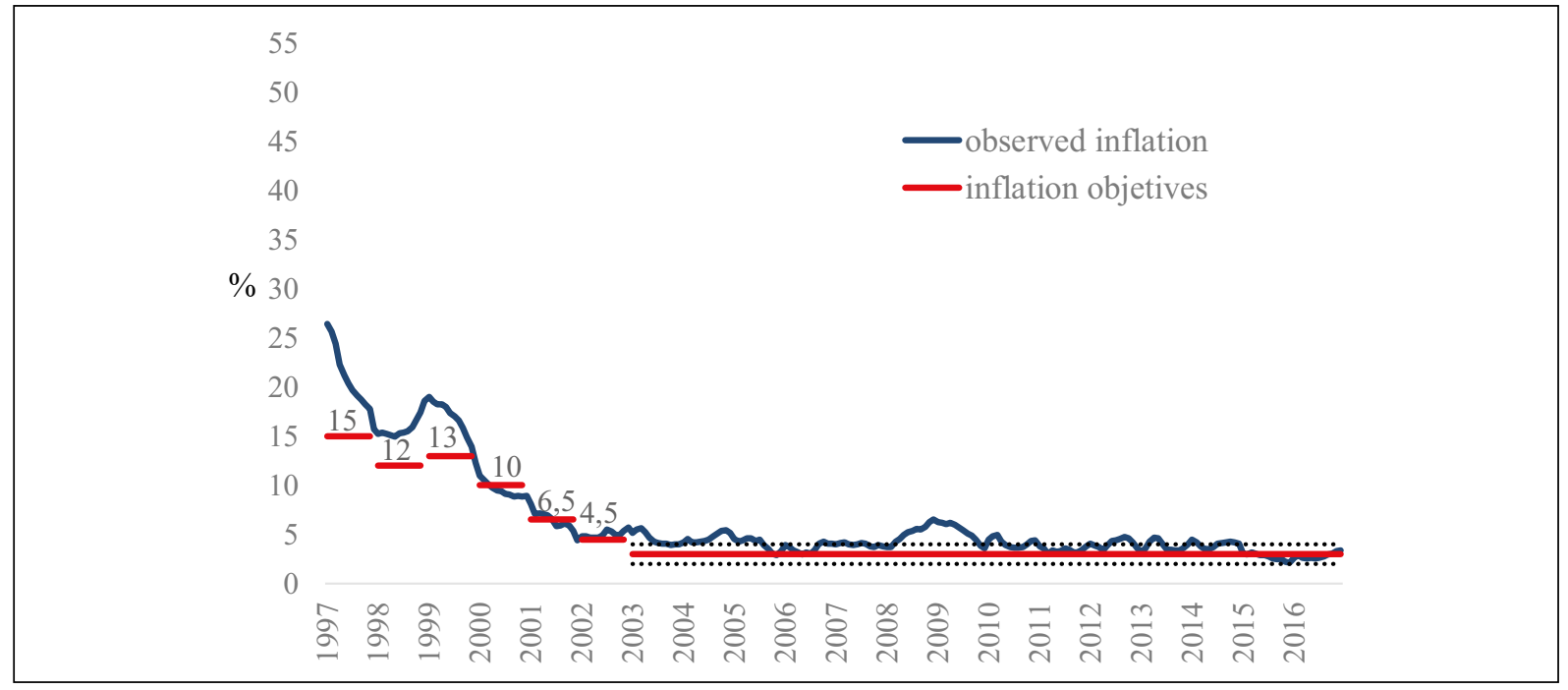

Source: Elaborated with information from BM and INEGI. 
The adoption ITA by the BM increased the activities of transparency and taking hold of accounts from the authority to private agents. Similarly, the elaboration of a "Quarterly Report" in 2001 and a calendar to communicate monetary policy decisions were added to regular publications. Undoubtedly the most significant measure taken, however, was when the authority began to fix the level of the interbank interest rate (IIR) in 2008, which would move on the order of 25 base points (BP) substituting the zero average reserve requirement and in so doing converting it into the primary instrument through which BM enacts and communicates its monetary policy posture.

\section{Transmission mechanisms for the monetary policy}

The mechanism of transmission of the BM's monetary policy is represented in Figure 2, which demonstrates that inflation surges due to demand pressures (aggregate demand) and/or supply pressures (aggregate supply). The BM fixes its monetary posture by increasing or decreasing, depending on the case, the level of the IIR on the order of 25 BP (or this can be left unchanged). This activity is then transmitted to the economy through distinct channels: i) channel of interest rates, ii) channel of credit, iii) channel of prices of other assets, iv) channel of exchange rate and $v$ ) channel of expectations. The first three impact aggregate demand and the last two affect aggregate supply. It is worth highlighting that the exchange channel has repercussions on both aggregate supply and aggregate demand.

In the case of the channel of interest rates (also known as the channel of traditional transmission), a restrictive action (versus relaxed action) provokes a rising displacement of the curve of intertemporal performances of all the interest rates in the economy (Apotela, Ardavín \& Cruz, 2001). Said increases affect savings, investment and consumption, affecting aggregate demand and prices (Taylor, 1995). In the case of the channel of credit, a restrictive action (versus relaxed action) provokes a rise in the interest rate, influencing the supply and demand of credit, negatively impacting investment spending, aggregate demand and price formation (Bernanke \& Blinder, 1992). In the case of the type of exchange, a restrictive action (versus relaxed action) provokes a rise in the interest rate, which appreciates local currency with respect to foreign currency, influencing goods produced internally with respect to foreign goods, which in turn impacts the prices of imported goods and costs, on aggregate supply and prices (Copelman \& Werner, 1995; Baqueiro, Díaz de León \& Torres 2003; Calvo \& Reinhart, 2002).

\section{Figure 2.}

Transmission mechanism for the monetary policy.

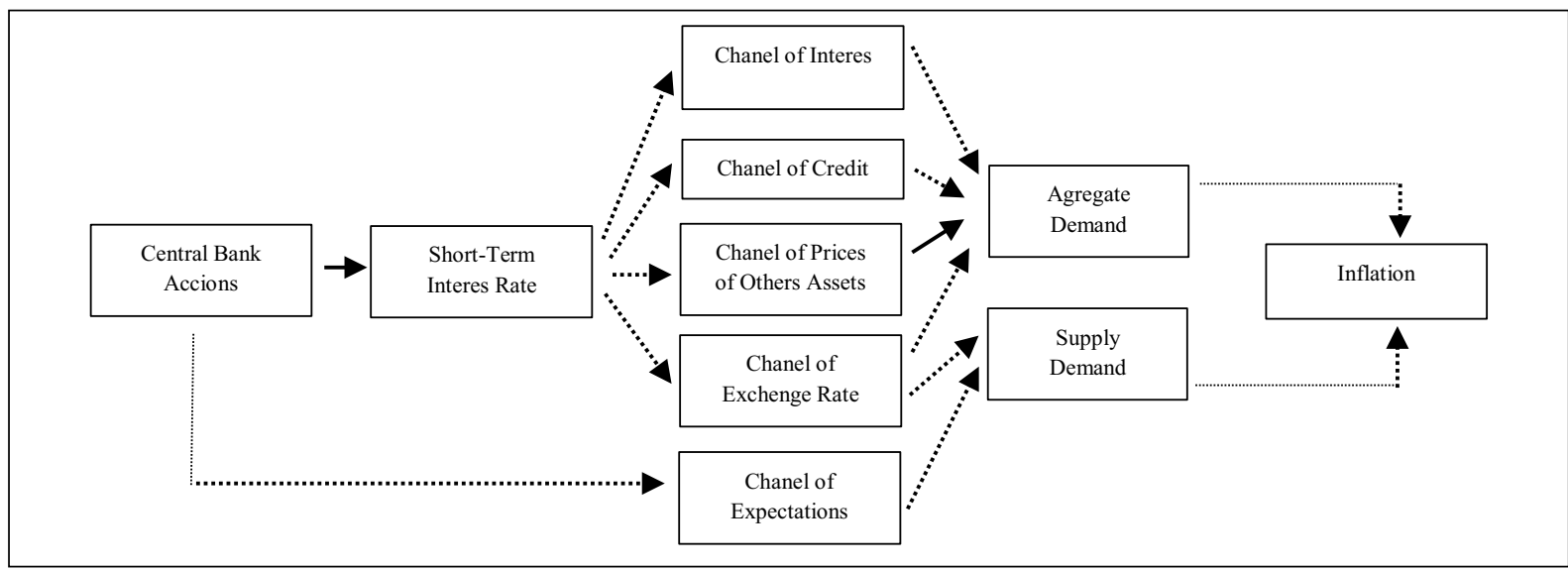

Source: Elaborated with information from Banco de Mexico (2003b). 
With respect to the price channel for other financial actors, a restrictive action (versus relaxed action) increases the interest rate affecting the value of the market for businesses and consumer wealth (Mishkin, 1996). On the one hand, an increase in the interest rate makes bonds more attractive and makes buying stocks less attractive, which lowers the price of the market for businesses. Consequently, firms face difficulties in new investments, interrupting their growth and influencing aggregate demand and prices. On the other hand, an increase in the interest rate and the reduction of the price of stocks diminishes the value of investment portfolios for families and with this, their wealth decreases, provoking lower consumption, less aggregate demand and drop in price formation (Mishkin, 1995; Mishkin, 2011). In sum, the interest rate rises and the rhythm of economic activity tends to diminish, as do prices.

To illustrate the effects of monetary policy on the economy, we can consider two examples. The first refers to a scenario, in which the restrictive monetary policy fights against inflation and BM rises by $25 \mathrm{BP}$ or multiples of it the level of IIR. This action $a$ ) increases the cost of money, causing diminishing investment and consumption-the result being a decrease in aggregate demand and prices; $b$ ) diminishes the availability of credit, the investment spending of businesses and reduces the aggregate demand and prices; $c$ ) increases the attractiveness of bonds to the detriment of the stocks of businesses, which decrease their investments, leading to a reduction in aggregate demand and prices; d) provokes an appreciation of the Mexican peso with respect to the American dollar, fortifying imports, reducing cuts, aggregate demand and price formation; $e$ ) rapid influence on the forecasts of economic agents, who trust that the BM will act to prevent deviations of inflation from its target. The agents will make daily economic decisions based on the inflation target announced by BM, which is to say they will not take on contracts with an inflation greater than the goal stated by the authority. The public trusts that the BM will comply with the goal they themselves set, which in the case of Mexico is $3 \%$ in the long-term. In sum, the interest rate rises and the rhythm of economic activity tends to diminish, as do prices.
The second example envisions a scenario in which a relaxed monetary policy stabilizes the economy and employment. In this case, the BM perceives an expected weakness in economic growth and employment, and thus lowers by $25 \mathrm{BP}$ or multiples therefore the level of the IIR. Such action a) diminishes the cost of money, generating an increase in investment and consumption, the result being an increase in aggregate demand and production; $b$ ) increases the availability of credit, the investment spending of businesses and increasing aggregate demand and production; $c$ ) diminishes the attractiveness of bonds in favour of business actions, with businesses investing more and increasing aggregate demand and production; $d$ ) provokes a depreciation of the peso with respect to the dollar, fortifying exports, increasing aggregate demand and production; e) decreases the IIR index rapidly in the hopes that economic agents, recognizing a drop in the cost of money, would incentivize investment, consumption, production of goods and services, and income generation among the population. Soon the economy begins to breathe again in the face of the weakness it has experienced. In sum, the low interest rate and rhythm of economy activity tend to rise.

The BM works with a unique mandate, meaning that the weighing of its monetary policy decisions are done completely through the control of inflation. This suggests that the BM does not react in the face of deviations of the GDP, or rather, that the recommended real interest rate could be affected only by deviations of inflation. The latter implies that giving weight to both objectives generates intermediate results.

\section{Review of literature on the subject}

The qualitative analysis of the monetary easing of cycles in Mexico is recent, so there is limited literature on the subject. However, if an attempt is made to analyze the BM's response to the weakening of output and employment, quantitative research work is available. Galindo \& Guerrero (2003), who estimate a Taylor's rule for Mexico from 1990-2000, argue that the BM focuses its efforts on controlling inflation. There is also Villagómez \& Orellana (2009), who estimate a small-scale macro model of small scale from 1998 to 2008 and find that the BM has 
a preference for stabilizing the output and not just inflation.

In his turn, Pérez (2012) also estimates, a Taylor rule for Mexico from 2002 to 2012 and points out that within the objectives of the issuing institute is to stabilize the output. In the case of Rodríguez \& Alvarado (2016) they also estimate a Taylor rule from 2000 to 2012 and find that the interest rate policy follows the output, although with some statistical weakness in the model. Although these works are different in terms of the periodicity of their studies, they allow to see changes in BM's preferences regarding following the output.

\section{METHODOLOGY}

We analyse official information of the Banco de México from 2009 and 2013-2014 to have data that shows the cuts made to the reference rate, as well as both the periodicity and the quantity of said cuts. In 2009 and 2013-2014 there were two periods of slowdown in economic activity. We carefully review the following BM documents: Informe Anual de 2009, Recopilación de Informes Trimestrales Correspondientes al Año 2013, Recopilación de Informes Trimestrales Correspondientes al Año 2014, Programa de Política Monetaria para 2009, Programa de Política Monetaria para 2013, Programa de Política Monetaria para 2014, Informe sobre Política Monetaria para el Primer Semestre de 2009, Informe sobre Política Monetaria para el Segundo Semestre de 2009, Informe sobre Política Monetaria para el Primer Semestre de 2013, Informe sobre Política Monetaria para el Segundo Semestre de 2013, Informe sobre Política Monetaria para el Primer Semestre de 2014, Informe sobre Política Monetaria para el Segundo Semestre de 2014, Informe de Inflación EneroMarzo de 2009, Informe de Inflación Abril-Junio de 2009, Informe de Inflación Julio-Septiembre de 2009, Informe de Inflación 0ctubre-Diciembre 2009, Informe de Inflación Enero-Marzo 2013, Informe de Inflación Abril-Junio 2013, Informe de Inflación Julio-Septiembre 2013, Informe de inflación Octubre-Diciembre 2013, Informe de Inflación Enero-Marzo 2014, Inflación de Informe Abril-Junio de 2014, Informe de Inflación Julio-Septiembre de 2014 and Informe de Inflación Octubre-Diciembre de 2014.
Likewise, the Announcements of the Monetary Policy Decisions of BM were analyzed for the following dates: January 16, 2009; February 20, 2009; March 20, 2009; April 17, 2009; May 15, 2009; June 19, 2009; July 17, 2009; August 21, 2009; September 18, 2009; October 16, 2009; November 27, 2009; January 18, 2013; March 8, 2013; April 26, 2013; June 7, 2013; July 12, 2013; September 6, 2013; October 25, 2013; December 6, 2013; January 31, 2014; March 21, 2014; April 25, 2014; June 6, 2014; July 11, 2014; September 5, 2014; 0ctober 31, 2014 and December 5, 2014. Finally, the Minutes of the Meetings of the Board of Government of the BM on the following dates: January 18, 2013; March 8, 2013; April 26, 2013; June 7, 2013; July 12, 2013; September 6, 2013; October 25, 2013; December 6, 2013; January 31, 2014; March 21, 2014; April 25, 2014; June 6, 2014; July 11, 2014; September 5, 2014; October 31, 2014 and December 5, $2014^{1}$.

Our analysis of the IIR represents the BM's primary monetary policy instrument for fighting inflation and influencing the economic cycle. Movements of the rate impact the economy through distinct channels of transmission, with these channels impacting aggregate supply and demand (Mishkin, 1995), as you can see lines below.

\section{RESULTS}

\section{The first cycle of monetary easing in 2009}

In January of 2009, the Bank of Mexico initiated a cycle of monetary easing of its' monetary posture which continued through the months of February, March, April, May, and June, concluding in July. During this interval the level of the reference rate passed from $8.25 \%$ in January to $4.5 \%$, the motivation for which was the deterioration of the balance of risks in the economy. This rate reduction occurred in the following stages: a drop in January of $50 \mathrm{BP}$, in February of $25 \mathrm{BP}$, in March of $75 \mathrm{BP}$, in April of 75 BP, in May of 75 BP, in June of 50 BP, and, finally, in July of $25 \mathrm{BP}$. The economic context in which this decrease in the cost of money developed was the following:

1 It is important to say that in the tex $t$ we quote only those references that were used for this research. 
According to Board of Governors of the Federal Reserve System (BGFRS) the devastating collapse of Lehman Brothers (the fourth biggest investment bank in U.S.) in August of 2007 signified the spread of the financial crisis into economic activities and marked without doubt the most severe point of the crisis' contingency (BGFRS, 2008; BGFRS, 2009; Rojas, 2017). The global growth diminished $0.6 \%$, experiencing the first global contraction since the post-war period. The U.S. witnessed a $2.4 \%$ fall in its output, the biggest decrease in more than six decades (Rojas, 2015b). Similarly, the Mexican economy was seriously affected by the contagion of the crisis, with a decline of $6.5 \%$ in its economic activity - something not seen since the crisis of 1994-95. The outbreak of the AH1N1 influenza virus in Mexico added to the devastating effects of the global crisis in the first semester of 2009. For several days economic activities were almost completely paralyzed, affecting a broad panoply of financial sectors including commerce, local export industries, tourism and commercial aviation.

The economic crisis that was already having a global impact inevitably affected Mexico, and the point of contagion was the external sector, which is to say the exports from Mexico to its primary trading partner. Similarly, internal production diminished, putting the brakes on the influx of foreign exchange via tourism, direct investments and capital, and the remittances sent by foreign nationals. The automotive sector was among those most severely affected by the crisis, due to its substantial dependence on the Mexican export industry, which was seriously impacted when two of the principle assembly plants in the U.S. reached the point of collapse. The interdependence that exists between the external sector, export-related activities and industries, and the internal market spurred a rapid deceleration of the Mexican economy. The contagion ultimately resulted in an $8.9 \%$ fall in the Mexican output in annual terms, and a fall of $6.9 \%$ and $0.3 \%$ in the first and second quarters of the year, respectively (Banco de Mexico, 2010).

In 2008, the majority of the central banks of the world's principal economies had significantly relaxed their monetary policy, with the goal of lowering the cost of money and assuaging the crisis. The weakness of the global economy was such that central banks caught a dire glimpse of the future: extremely low interest rate levels for a prolonged period to come. In addition to conventional monetary policy actions, non-conventional actions were taken to increase the balance sheets of the Fed, which had served for more than a century as the United States' central bank (Rojas, 2014; Rojas, 2015a; Rojas 2017). Once the global financial turbulence subsided, global capital flows changed, migrating from secure to risky positions, following the incentive offered by the differential rates of emerging markets with respect to developed markets. This provoked an inflow of resources to the former, slowing the brusque depreciations which had been occurring in developing countries.

This situation allowed a diverse range of central institutions from developing nations, including Mexico, to utilize their monetary policy to confront the economic weakness surging through their economies, a move made possible by the institutional credibility already generated. In addition to the aforementioned monetary supports, contra-cyclic fiscal policies were added although in lesser quantities. In a context of a decelerating global economy with decreasing supply shocks for the economies of developing countries, inflation was not the foremost problem in the majority of those nations. Mexico, in turn, was no exception, witnessing considerable decreases in inflation: of $6.5 \%$ and $3.5 \%$ in 2008 and 2009 , respectively (Guzmán, 2016).

In the economic context outlined above, the Bank of Mexico began, in January of 2009, a cycle of easing of its monetary posture which continued through the months of February, March, April, May, June and terminated in July. During this period the reference rate level fell from $8.25 \%$ in January to $4.5 \%$, the motivation for which was purportedly that "the balance of risks in the economy had deteriorated" (Banco de Mexico, 2010). This decline in the interest rate proceeded in the following manner: $50 \mathrm{BP}$ in January, 25 BP in February, 75 BP in March, 75 BP in April, 75 BP in May, 50 BP in June, and finally $25 \mathrm{BP}$ in July (Figure 3). 


\section{Figure 3.}

$\Delta \%$ Gross national product and $\%$ interbank interest rate from 2008.I to 2011.IV

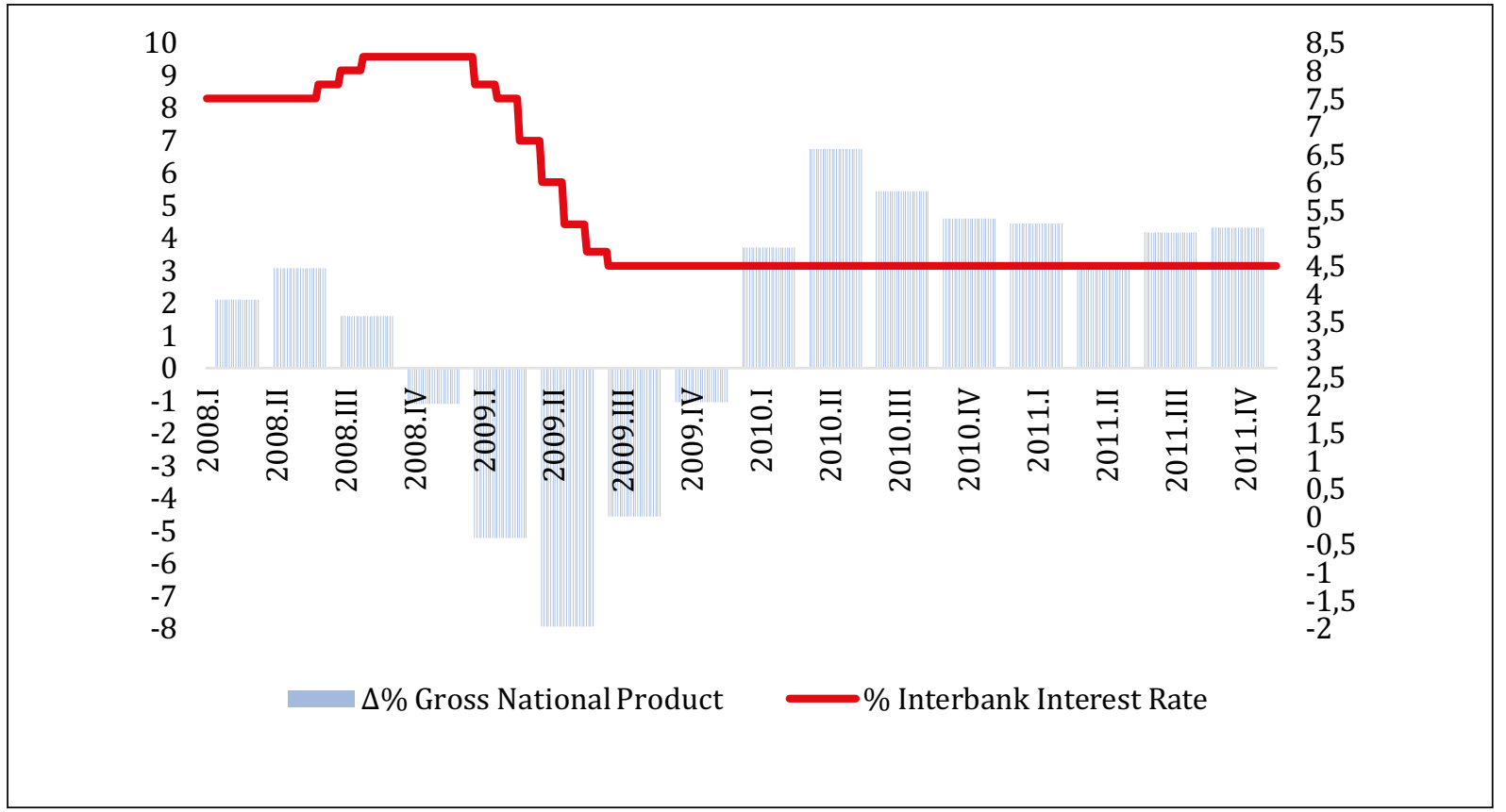

Source: Elaborated with information of INEGI and BM.

According to the minutes from the Governor's meeting of the Bank of Mexico, bank officials argued for something new in Mexico's monetary practice, stating that the balance of risks facing monetary policy was being affected by the evolution of economic activity and that now it was not inflation but rather the output and perhaps also unemployment, which were the primary concerns. On this point, it must be mentioned that the possibility for the Mexican issuing institute to initiate countercyclical policy is due to the credibility built up since the constitutional reform of 1994 and the strengthening of that credibility when focused inflation targets were adopted. The start of the cycle of monetary easing began with the monetary policy announcement of January 16, 2009, when the rate dropped $50 \mathrm{BP}^{2}$, passing from $8.25 \%$ to $7.75 \%$ (Banco de México, 2009a).

Subsequently, on April 20, 2009, the BM lowered the rate by $75 \mathrm{BP}$. The rate dropped from $6.75 \%$ to $6 \%$,

2 The components of the balance of risks have deteriorated, especially in what is referred to as economic activity with regard to inflation. and the following was commented: "The important drop that has been registered in the economic activity has required preventative monetary policy actions that contribute to mitigate unfavorable impacts of the crisis" (Banco de México, 2009b, p.1).

Subsequently, the announcement of June 19, 2009, lead to a drop of $50 \mathrm{BP}$ and the rate passed from $5.25 \%{ }^{3}$ to $4.75 \%$ (Banco de México, 2009d). Finally, the cycle of monetary easing concluded with the announcement by BM on July 17, 2009, which informed of a reduction of the rate, which dropped from $4.75 \%$ to $4.5 \%$, with a concomitant reduction of $25 \mathrm{BP}^{4}$ (Banco de Mexico, 2009e).

As shown, the Bank of Mexico made base point reductions of the monetary instrument IIR with the objective of exerting a positive influence over

3 The monetary policy actions taken until now have been of a preventative character.

4 With respect to this the authorities noted that the Board of Governors has decided to reduce by $25 \mathrm{BP}$ the interbank interest rate for the day, to a level of 4.50 percent and put a pause on the cycle of monetary easing. 
aggregate demand. That is to say it was motivated to stimulate the output through incentives which were translated into cheaper credits to increase productive investment and, with this, reduce the unemployment rate.

\section{The second cycle of monetary easing, 2013-2014}

The central bank initiated a second cycle of monetary easing in March of 2013 with a 50 BP cut to the reference rate, which dropped from $4.5 \%$ to $4 \%$. The quantitative easing continued with reductions of $25 \mathrm{BP}$ for the months of September and October respectively. The rate passed from $4 \%$ to $3.5 \%$, which meant that the issuing authority had aggregated a drop of 150 BP in 2013 and 2014, with the argument that the increase of the gap in the output was evidence of a greater weakness in the Mexican economy (Carstens, 2015).

The Mexican economy began to decelerate towards the second semester of 2012, after having grown to annual rates of $5 \%$ in $2009,5.2 \%$ in $2010,4.9 \%$ in 2011 and finally $3.9 \%$ in 2012. In the second semestre of 2012, the economy lost dynamism, due to the great expenditure associated with the presidential elections, and this deceleration continued with greater force in the first semester of 2013. This loss of economic drive was undoubtedly due to the economic problems in the U.S. (Mexico's primary business partner) and the loss of force of Mexico's internal market.

In 2013, after five years of non-conventional monetary actions on behalf of the Fed, that institution was preparing to normalize its monetary policy (Rojas, 2015b). This generated a reaccomodation of investment portfolios across practically the entire world, generating in turn a reshuffling of investment funds. International capital began to flow from developed to developing nations, generating volatility and instability in the international financial markets. The volatility was strongest in exchange markets, falling mostly on developing countries, including Mexico. The result was an appreciation of the peso with respect to the dollar in the first semester of 2013, and subsequently a depreciation of the Mexican currency in the second semestre of that year. The appreciation of the peso against the dollar in the first semester of 2013 weakened the dynamism of Mexican exports in the U.S. In the second half of 2013, the powerful outflow of capital devalued the peso against the dollar, newly incentivizing sales from Mexico to its northern neighbour (Banco de Mexico, 2014b).

With the change of government in Mexico in 2014, the public expenditure ceased to flow adequately, slowing down due to the processes of transition and learning of the new high level officials. Consumer confidence had ceased growing since the second semester of 2012 and began to fall with force in the first semester of 2013. What contributed further to the loss of momentum in the internal market was undoubtedly the weakness of the housing sector, which crashed when the incoming federal government drastically modified the rules of the game in the country's housing industry. Lowered consumption, investment and government spending all accentuated the deceleration of the economy towards the first half of 2013 (Esquivel, 2013).

This weakening resulted in a broadening of the gap in output, understood as the difference between the observed output and the potential output. With this indicator in mind and, with the reference rate having remained unchanged, the BM decided to initiate a second cycle of monetary easing in march of 2013 to shore up the economy, lowering the IIR by $50 \mathrm{BP}$ to the level of $4 \%$ (Banco de Mexico, 2013b).

The foregoing aside, in the months that followed, the public spending continued to flow slowly, without reaching previous crisis levels, while weakened private consumption continued and the construction sector remained in freefall. Housing companies were facing a difficult financial situation, to the extent that they began entering into processes of trade competition for their liquidation. To reinforce the weak-although still positive-economic growth, the central bank decided to implement new cuts to the reference rate target, of $25 \mathrm{BP}$ in September and October, respectively. The rate objective dropped from $4 \%$ to $3.5 \%$, signifying that the issuing institute authored a loss of 100 BP in 2013 as you can see Figure 4 (Banco de Mexico, 2013c). 


\section{Figure 4.}

$\Delta \%$ Gross national product and $\%$ interbank interest rate from 2011.I to 2014.IV

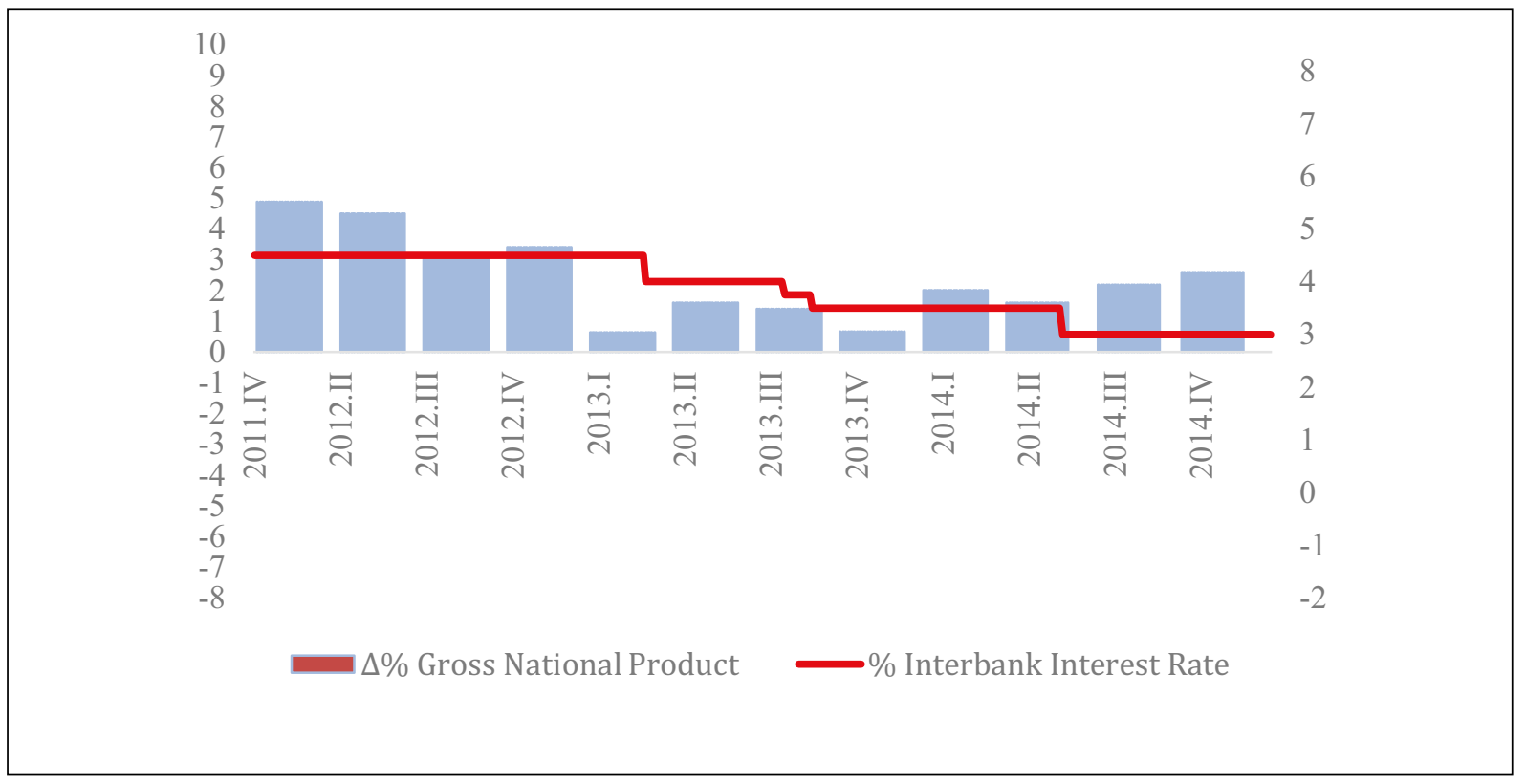

Source: Elaborated with information of INEGI and BM.

To that end, monetary support on behalf of the central bank would be added an attempted fiscal policy of a relatively abnormal nature: a housing reform which proposed to increase taxes and public spending. With this, government expenses increased by nearly $10 \%$ in 2014, as compared to the previous year. Right from the start, the business sector looked askance at the proposal to increase taxes, public debt, and the amount of public spending; considering it a set of poorly proposed fiscal supports, if indeed this was what the government truly wanted.

The housing reform began to negatively influence the mood of the public from the moment it was approved by the permanent constituency. The reform included the abolition of the single rate business tax (Impuesto Empresarial a Tasa Unica or IETU) and the tax on cash deposits (Impuesto a los Depósitos en Efectivo or IDE), the unification of the tax on aggregated value (Impuesto al Valor Agregado or IVA) across the border region, the new levies on sugar-sweetened beverages and high-caloric foods, a new tax on gasoline, the elimination of special regimes, higher levies on high wage-earners and a tax on dividends and capital gains.
In 2014, the BM began the year with an ambitious fiscal plan to support growth as well as the continuation of the laxer monetary policy put in place during the previous year. It was seen by old Keynesians as the best of all possible worlds, fiscal politics and monetary expansiveness. Nevertheless, the Mexican economy did not seem to respond well. One of the primary reasons was because in the first trimester of the year, the U.S. economy lost momentum due to adverse climatic conditions, principally along the country's eastern coast. Mexican exports to the U.S. decelerated, negatively impacting growth and the creation of employment, though this negativity would dissipate to a certain degree over the following months. 2014 was characterized by an increase in public spending, most notably in investments in public works and social programs. Despite the increase in public expenditure contained in the new fiscal package, economic activity remained weak through the first trimester of 2014 (Banco de Mexico, 2014b).

For its part, the BM decided in June of that year to once again cut the IIR rate, from 3.5 to 3.0 , considering the continuing growth of the gap in output, 
which was perhaps worsened by the operationalization of the structural reforms approved by Congress. It is without doubt that the BM was concerned about the deceleration of economic activity and decided to extend the cycle of monetary easing which had begun in March of 2013.

As demonstrated, the BM undertook a second cycle of monetary easing by means of successive cuts to the target of the IIR rate, with the objective of influencing productive activities (Banco de Mexico, 2014d). The BM incorporated new monetary incentives, which translated into more spending on productive investment, greater aggregate demand, and a rise in the economy. It was among the arguments put forth by the $\mathrm{BM}$ to justify lowering the target from $4.5 \%$ to $4 \%$, which is to say by $50 \mathrm{BP}^{5}$, in March of 2013 (Banco de Mexico, 2013a).

For its part, in the Minutes of Monetary Policy (Minuta de Política Monetaria) number 22, it argued that: "the majority of members of the Board asserted that the balance of risks for growing the Mexican economy has deteriorated" (Banco de Mexico, 2013d, p.22) and the institute considered that "the production gap is in negative terrain and that it is expected to remain below zero at least until 2014" (Banco de Mexico, 2013d, p.14). After the BM lowered the target of the rate from $4 \%$ to $3.5 \%$ in September and October of 2013, by 25 BP, respectively (Banco de Mexico, 2013b; Banco de Mexico, 2013e).

In June of 2014, the BM cut for a final time the reference rate, which dropped from $3 \%$ to $4 \%{ }^{7}$ (Banco de Mexico, 2014a; Banco de Mexico, 2014c). Ample qualitative evidence exists to show that the BM undertook and oversaw two cycles of monetary easing, in 2009 and 2013-2014, and in both cases diminished the cost of money in the country in an

5 This reduction in the reference interest rate for the monetary policy facilitated the adjustment of the economy to an environment of lower economic growth and less inflation.

6 In the second quarter of the year the weakening of economic activity was generalized and faster than anticipated, which gave rise to a contraction of the output in the quarters and a significant increase in the width in the economy.

7 The members of the Board of Governors asserted that the ordered control over public finances permits in turn a greater flexibility in the management of monetary policy. effort to drive economic activity and employment. The minutes from the meeting of the board of governors of that institution clearly demonstrate the posture of its officials with respect to the gap in output and providing support for the former claim.

\section{CONCLUSIONS}

At the end of the 20th century, Mexico undertook a change in its economic model, a change which would continue and be further reinforced in the 21st century, generating a structural change in the economy and all of its institutions. The central bank put into motion a structural shift which would not be undone. It was granted administrative and managerial autonomy and-for the first time in its' history-its primary, driving objective became battling inflation, while it cancelled the possibility of financing the government through the creation of money. With inflation at single digit levels in this century, BM adopted ITA as the marker for good monetary policy practice among the world's central banks. A long-term inflation target of 3\% was made official and the actions of the monetary authority were made more transparent. Inflation has been low, hovering around 3\% in the last 10 years. The primordial objective has been to safeguard the acquisitive power of the Mexican peso.

Nevertheless, in 2009 and 2013-2014, the BM undertook efforts to stabilize the output in the face of the financial crisis in the U.S., and to reverse the deceleration of the Mexican economy, which coincided with the new Mexican government. Its activities shifted from guiding inflation to the new target of stabilizing output around its potential output level. It appeared that the central bank's actions were being controlled via the use of a Taylortype policy rule, which describes the movement of interest rates in response to deviations of inflation from its desired level or target (the inflation gap) and the diversion of the output from its natural rate level (the output gap).

The members of the board of governors of the BM directed two cycles of target lowering for the IIR because the economy was growing below the level of its output potential. The BM was concerned not only about inflation, as in the 1980s, but 
moreover about the low growth of the economy. The question this raises academically is whether in the future: will it be necessary to reform article 28 of the Constitution to include the promotion of the output and employment as an objective of the BM, such as in fact exists in the U.S. legislation? Further investigation is required to determine via quantitative measures whether cuts to the IIR had a positive impact on the behavior of the output and of employment. This is without a doubt an important area for further research.

\section{BIBLIOGRAPHIC REFERENCES}

Apotela, F., Ardavín, J.A. \& Cruz, Y. (2001). Comportamiento histórico de las tasas de interés reales en México, 1951-2001 (Documento de Investigación No. 2001-05). Recovered from the website of Banco de México http://www. banxico.org.mx/publicaciones-y-discursos/ publicaciones/documentos-de-investigacion/ banxico/\%7BDB45CF79-AEBE-8E82-223EA3FD3E1A6AA6\%7D.pdf

Aspe, A. (1993). El camino mexicano de la transformación económica. Ciudad de México: Fondo de Cultura Económica.

Banco de México. (1994). Informe Anual de 1993. Recovered from http://www.banxico.org.mx/ dyn/publicaciones-y-discursos/publicaciones/ informes-periodicos/anual/\%7B3E0CB2BC635F-356D-2F76-6D689D09C84B\%7D.pdf

Banco de México. (1995). Informe Anual de 1994. Recovered from http://www.banxico.org.mx/ dyn/publicaciones-y-discursos/publicaciones/ informes-periodicos/anual/\%7BF1A0007521D4-5DCF-D124-09CB6EF16235\%7D.pdf

Banco de México. (2001). Esquema de Objetivos de Inflación. Recovered from http://www.banxico. org.mx/dyn/politica-monetaria-e-inflacion/ material-de-referencia/intermedio/politicamonetaria/\%7B5C9B2F38-D20E-8988-479A922AFEEBB783\%7D.pdf

Banco de México. (2003a). Informe Anual de 2002. Recovered from http://www.banxico.org.mx/ dyn/publicaciones-y-discursos/publicaciones/ informes-periodicos/anual/\%7B16ECB401-6EFF90E0-1770-2420A397D9FA\%7D.pdf

Banco de México. (2003b). Efectos de la Política Monetaria sobre la Economía. Recovered from http:// www.banxico.org.mx/politica-monetaria-einflacion/material-de-referencia/intermedio/ politica-monetaria/\%7BC6564A4C-E7F7-50E86056-C9062C9D05CC\%7D.pdf

Banco de México. (2009a). Anuncio de Política Monetaria. Recovered from http://www.banxico.org.mx/ dyn/informacion-para-la-prensa/comunicados/ politica-monetaria/boletines/\%7B3195E1AB0318-FC6F-12B8-B61CB9564F9F\%7D.pdf

Banco de México. (2009b). Anuncio de Política Monetaria. Recovered from http://www.banxico.org.mx/ dyn/informacion-para-la-prensa/comunicados/ politica-monetaria/boletines/\%7BFFE4D3F19357-DB20-8D78-1B647BEDB36F\%7D.pdf

Banco de México. (2009c). Informe Anual de 2008. Recovered from http://www.banxico.org.mx/ dyn/publicaciones-y-discursos/publicaciones/ informes-periodicos/anual/\%7BE2479C9947CB-19B8-92A7-D011876E8FCA\%7D.pdf

Banco de México. (2009d). Anuncio de Política Monetaria. Recovered from http://www.banxico.org.mx/ dyn/informacion-para-la-prensa/comunicados/ politica-monetaria/boletines/\%7B6E9BFDC1D430-63DF-D803-21E2B2EC887F\%7D.pdf

Banco de México. (2009e). Anuncio de Política Monetaria. Recovered from http://www.banxico.org.mx/ dyn/informacion-para-la-prensa/comunicados/ politica-monetaria/boletines/\%7BF3683EEA29F5-BB1B-C5C7-FF265712A8A8\%7D.pdf

Banco de México. (2010). Informe Anual de 2009. Recovered from http://www.banxico.org.mx/ dyn/publicaciones-y-discursos/publicaciones/ informes-periodicos/anual/\%7BE1FEC59E-65CEBF0B-CF0D-F25651B6EDBC\%7D.pdf

Banco de México. (2013a). Informe Trimestral EneroMarzo 2013. Recovered from http://www. banxico.org.mx/dyn/publicaciones-y-discursos/ publicaciones/informes-periodicos/trimestralinflacion/\%7BA36C38AB-5EAD-46F4-126C85ED8E11FFC3\%7D.pdf

Banco de México. (2013b). Informe Trimestral Abril-Junio 2013. Recovered from http:// www.banxico.org.mx/publicaciones-y-discursos/publicaciones/informes-periodicos/ trimestral-inflacion/\%7B267954D6-CD39-39BEAD88-3AD0ECCC47BC\%7D.pdf

Banco de México. (2013c). Informe Trimestral Octubre-Diciembre. Recovered from http:// 
www.banxico.org.mx/dyn/publicaciones-ydiscursos/publicaciones/informes-periodicos/ trimestral-inflacion/\%7B452EDDD5-0EAC-9E143870-11A49EC6835D\%7D.pdf

Banco de México. (2013d). Minuta número 22. Recovered from http://www.banxico.org.mx/ dyn/informacion-para-la-prensa/comunicados/ politica-monetaria/minutas-de-las-decisionesde-politica-monetaria/\%7B781A74C3-7E42B66E-07CD-E12E96559901\%7D.pdf

Banco de México. (2013e). Minuta número 23. Recovered from http://www.banxico.org.mx/ informacion-para-la-prensa/comunicados/ politica-monetaria/minutas-de-las-decisionesde-politica-monetaria/\%7B1EC22FAB-F7662E9A-50AD-703E6B9617CD\%7D.pdf

Banco de México. (2014a). Minuta número 28. Recovered from http://www.banxico.org.mx/ dyn/informacion-para-la-prensa/comunicados/ politica-monetaria/minutas-de-las-decisiones-depolitica-monetaria/\%7BFB222259-27D2-508BFF27-DE648B0AA82F\%7D.pdf

Banco de México. (2014b). Informe Trimestral EneroMarzo. Recovered from http://www.banxico. org.mx/dyn/publicaciones-y-discursos/ publicaciones/informes-periodicos/trimestralinflacion/\%7B84775B57-7E69-8BA4-A476FE4CF903200F\%7D.pdf

Banco de México. (2014c). Informe Trimestral Resumen Abril-Junio. Recovered from http:// www.banxico.org.mx/publicaciones-y-discursos/publicaciones/informes-periodicos/ trimestral-inflacion/\%7BA6268605-9EAD-996E4301-F884041BD651\%7D.pdf

Banco de México. (2014d). Informe Trimestral Octubre-Diciembre. Recovered from http://www. banxico.org.mx/dyn/publicaciones-y-discursos/ publicaciones/informes-periodicos/trimestralinflacion/\%7BCD08EC33-68C4-C3C2-25F869C5786988B8\%7D.pdf

Baqueiro, A., Díaz de León, A. \& Torres, G. (2003). Temor a la flotación o a la inflación. La importancia del «traspaso» del tipo de cambio a los precios. (Documento de Investigacion No. 2003-02). Recovered from the website of Banco de Mexico: http://www. banxico.org.mx/publicaciones-y-discursos/ publicaciones/documentos-de-investigacion/ banxico/\%7BFA9DE1DB-AC64-6D8C-CCE3881A0D62A92B\%7D.pdf
Bernanke, B., Laubach, T., Mishkin, F. \& Posen, A. (2001). Inflation Targeting. New Jersey: Princeton University Press.

Bernanke, B. \& Blinder, A. (1992). The Federal Funds Rate and the channels of monetary transmission, American Economic Review, 82(4), pp. 901-921.

Board of Governors of the Federal Reserve System - BGFRS. (2008). Monetary Policy Report. Recovered from https://www.federalreserve.gov/monetarypolicy/files/20080227_mprfullreport.pdf

Board of Governors of the Federal Reserve System -BGFRS. (2009). Monetary Policy Report. Recovered from https://www.federalreserve.gov/monetarypolicy/files/20090224_mprfullreport.pdf

Cabrera, J. \& Rojas, M. (Ed.). (2006). Apertura y balanza comercial. En J. C. Adame (Ed), Cambio estructural de la economía mexicana. México City: Facultad de Economía, UNAM Press.

Carstens, A. \& Reynoso, A. (1997). Alcances de la política monetaria: marco teórico y regularidades empíricas en la experiencia mexicana (Documentos de Investigación No. 9705). Recovered from the website of Banco de Mexico: http://www. banxico.org.mx/publicaciones-y-discursos/ publicaciones/documentos-de-investigacion/ banxico/\%7B36F5AED6-C4AF-0B7F-B099420FD2B79FF4\%7D.pdf

Carstens, A. \& Werner, A. (1999). Mexico's monetary policy framework under a floating exchange rate regimen (Documento de Investigación No. 9905). Recovered from the website of Banco de Mexico: https:// www.imf.org/external/pubs/ft/seminar/2000/ targets/carstens.pdf

Carstens, A. (March, 2015). La banca preparada ante una gran oportunidad de desarrollo. En S. R. Ortega (Chairman), 78 Convención Bancaria. Conference held in the Asociación de Bancos en México, Acapulco, México.

Calvo, G. \& Reinhart, C. (2002). Fear of Floating. Quaterly Journal of Economic, 117(2), pp. 379-408.

Constitución Política de los Estados Unidos Mexicanos -CPEUM. (23-08-1993). Diario Oficial de la Federación de 1917. Recovered from http://www.dof.gob.mx/ Constitucion1917/constitucion_1917.pdf

Copelman, M. \& Werner, A. M. (1995). The monetary trasmission mechanism in Mexico (International Finance Discussion Papers No. 521). Recovered from the website of Board of Governor of the Federal Reserve System https://www.federalreserve.gov/pubs/ ifdp/1995/521/ifdp521.pdf 
Esquivel, G. (1 de noviembre de 2013). Una recesión 'hecha en México [Mensaje en un blog]. Recovered from http://www.nexos.com.mx/?p=15580

Friedman, M. (1968). The role of monetary policy. The American Economic Review, 58(1), pp. 1-17.

Friedman, M. (1991). La Economía monetarista. Barcelona: Gedisa.

Galindo, L. M. \& Guerrero C. (2003). La regla de Taylor para México: un análisis econométrico, Investigación Económica, 42(246), pp. 149-167.

Guzmán, J. (May, 2016). Evolución económica y política monetaria en México. En S. Segal (Chairman), Americas Society/Council of the Americas CFO Mexico City Forum. Conference held in 2016 Latin American Cities Conferences, Mexico City.

Sánchez, M. (January, 2011). La interminable tarea de la estabilidad de precios. En Ramirez, D. N. (Director), Ciclo de Conferencias Financieras. Conference held in Instituto Tecnológico de Estudios Superiores de Monterrey, Campus Monterrey, Monterrey.

Ruíz, M. C. (2016). Evolución de la política monetaria del Banco de México, 1925-1976 (Doctoral Thesis). Facultad de Economía UNAM, Mexico.

Mishkin, F. (1995). Symposium on the Monetary Transmission Mechanism. Journal of Economic Perspectives, 9(4), pp. 3-10.

Mishkin, F. (1996). The channels of monetary transmission: lesson for the monetary policy (Working Paper 5464). Recovered from the website of National Bureau of Economic Research http://www.nber.org/ papers/w5464.pdf

Mishkin, F. (2011). Monetary Policy Strategy: lessons from the crisis (Working Paper 16755). Recovered from the website of National Bureau of Economic Research http://www.nber.org/papers/w16755.pdf

Pérez, 0. (2012). Un estudio empírico de la regla de Taylor para México, Economía Informa, (375), pp. 55-67.

Rodríguez, 0., \& Alvarado, E. (2016). Inflation Targeting and Policy Rules. The Case of México, 2001-2012. Ciudad de México: Apple Academic Press.
Rojas, M. (2014). Fundación del Sistema de la Reserva Federal en Estados Unidos. Economía Informa, (385), pp. 56-69.

Rojas, M. (2015a). 100 años de inflación y de presidentes de la Fed. Economia Informa, (390), pp. 97-103.

Rojas, M. (2015b). El debate de las causas de la crisis financiera de Estados Unidos del 2008 ¿Fue adecuada la respuesta del FED? Perspectivas, 9(1), pp. 29-53.

Rojas, M. (2017). The debate over the origin of the Great Recession in the Unites States. Revista Norteamericana CISAN-UNAM, 12(1), pp. 79-103.

Solis, L. (1997). Evolución del sistema financiero mexicano hacia los umbrales del siglo XXI. Mexico: Siglo XXI.

Taylor, J. (1993).-Discretion versus policy rules in practice. Carnegie-Rochester Conference Series on. Public Policy, 39(1), pp. 195-214.

Taylor, J. (1995). The monetary transmission mechanism: an empirical framework. Journal of Economic Perspectives, 9(4), pp. 11-26.

Taylor, J. (Noviembre, 2000). Using monetary policy rules in emerging market economies. En G. Ortiz (Gobernador), Stabilization and Monetary Policy: The International Experience. Conference held in Banco de Mexico, Mexico City.

Turrent, E. (December, 2010). Las implicaciones comunicacionales de la transición hacia un nuevo régimen cambiario. En D. L. Castellanos (Chairman), $\checkmark$ Reunion de Comunicación Social de Bancos Centrales. Conference held in Banco Central de Venezuela, Caracas.

Villagómez, A. F. \& Orellana, J. (2009). Monetary Policy Rules in a small open economy: an aplication to Mexico (Working paper EGAP-2009-01). Recovered from the website of Tecnológico de Monterrey, Campus Ciudad de México: http://alejandria.ccm.itesm.mx/ egap/documentos/EGAP-2009-01.pdf 